\title{
Influence of Storage Temperature and Duration of Tomato Leaf Samples on Proline Content
}

\author{
Mohammad H. Brake \\ Hassan R. Hamasha
}

Science Department, Science Faculty, Jerash University, Jordan

Hussein M. Migdadi

Plant Production Department, College of Food and Agricultural Sciences,

King Saud University, Saudi Arabia

Ashraf O. Khashroum

Department of Plant Production and Protection, Agriculture Faculty, Jerash

University, Jordan

Moath Al-Gharaibeh

Muien M. Qaryouti

National Center for Agricultural Research and Extension, Jordan

Mahmoud T. AL-Khatib

Abstract

In arid and semi-arid countries such as Jordan, shortage in water sources might affect agricultural development and reduces the effectiveness of economic benefits of most crops planted in such areas. Tomato is an important agricultural crop and faces severe drought stress due to climate changes, therefore, measurement of proline accumulation in plant tissues is used as an indicator for drought stress tolerance. This research was conducted at Jarash University Campus in northern Jordan. A field experiment was carried out to investigate the impact of different storage temperature $\left(+4^{\circ} \mathrm{C}\right.$, $20^{\circ} \mathrm{C}$ and $\left.-80^{\circ} \mathrm{C}\right)$ and different storage durations $(0,3,6$ and 11 weeks) on proline content in five different Jordanian tomato landraces. Results indicated that the average free proline content for samples tested directly after leaves collection was $7.1 \mu \mathrm{mol} / \mathrm{g}$. Proline content in leaves stored at $+4{ }^{\circ} \mathrm{C}$ for 3,6 , and 11 weeks was $4.8,1.8$, and $1.1 \mu \mathrm{mol} / \mathrm{g}$, respectively, while for $-20^{\circ} \mathrm{C}$ was $11.8,7.9$, and $9.5 \mu \mathrm{mol} / \mathrm{g}$ for samples stored for $3,6,11$ weeks respectively. In contrast the highest values for these parameters were obtained from samples stored at $-80^{\circ} \mathrm{C}$, the average measured values of free proline content were 9.5 , 7.8 , and $12.9 \mu \mathrm{mol} / \mathrm{g}$ at 3,6 , and 11 weeks of storage, respectively. Based on the results obtained by this research, it is recommended to measure proline 
content directly after leaves collection. However, for large number of samples, keeping the samples at $-20^{\circ} \mathrm{C}$ not longer than six weeks could be a solution. Finally, we highly recommend the development of in-field method for measurement of free proline content.

Keywords: Proline, Solanum lycopersicum, Temperature, Duration of storage

\section{Introduction}

Tomatoes (Solanum lycopersicum L.) are important, popular and nutritious vegetable crop all over the world. Tomato is the top source of vitamin $\mathrm{A}$ and $\mathrm{C}$ in human diet, and contains high content of antioxidant compounds which offer a number of benefits to human health (Bilton et al., 2001). It is also plays a vital role in providing a substantial amount of dietary fiber, lycopene, $\beta$-carotene, phenolic compounds, iron, magnesium, niacin, potassium, phosphorus, riboflavin and thiamine, which prevents oxidative changes in the human body (Garcia-Closas et al., 2004; Cuartero et al., 2006; Deshmukh et al., 2012).

Water scarcity is a major problem worldwide and it is one of the main future challenges in a world of growing population and industrialisation (Smith, 2006). Due to the climatic changes in the last decades, Middle East region including Jordan suffers from several water related problems, which are expected to become more serious in the near future (Smith, 2006). In addition, semiarid, and arid lands suffer from many abiotic challenges to plant growth, including extreme temperatures, poor nutrient and water availability (Yang et al., 2009). For most tomato cultivars, salinity produces a reduction in seed germination, and inhibition of growth which causes a drop in fruit productivity (Cuartero et al., 2006). Therefore, the development of stresstolerant cultivars using conventional and molecular approaches must be taken in consideration (Barrow et al., 2008; Eisenstein, 2013).

Proline accumulation in plant tissues is used as indicator for drought stress in plant samples (Heerden and Villiers, 1996), Proline is a compatible osmolytes that accumulates in plant subjected to unfavorable environmental condition, primarily drought (Hu et al., 1992; Balibrea et al., 1997) and salinity (Bourgeais-Chaillou and Guerrier, 1992; Delauney and Verma, 1993). Accumulation of proline may be a part of general adaptation to adverse environmental conditions. Delauney and Verma (1993) reported a positive correlation between proline accumulation and adaptation to salinity. On the other hand, other studies reported a negative correlation between proline accumulation and tomato salt tolerance (Alarcon et al., 1994).

Proline was reported to have a role in osmoprotectant during osmotic stress (Yoshiba et al., 1997), osmoregulation under drought and salinity stresses might cause stabilization of protein, prevention of heat denaturation 
of enzymes and conservation of nitrogen and energy for a post-stress period (Aloni and Rosenshtein, 1984). Proline content reported to be the highest in leaves (Guerrier, 1998) and in tomato hybird Calli root (Guerrier, 1995). The aim of this work was to study the influence of storage temperature and duration on free proline content of tomato plants.

\section{Materials and methods \\ Plant materials}

Fresh young leaves were collected in June 2014 from five different Jordanian tomato landraces (Jo.951, Jo.952, Jo.956, Jo.995, and Jo.972). For each Jordanian tomato landraces, leaves samples were divided into four major groups. The first group contains fresh leaves and free proline content was directly measured ( 0 month of storage), whereas the other three groups were stored for 3, 6, and 11 weeks, respectively. Each group was further subdivided and stored at three various temperatures; $+4^{\circ} \mathrm{C},-20^{\circ} \mathrm{C}$, and $-80^{\circ} \mathrm{C}$. Hereafter, free proline content was measured after each storage period.

\section{Proline determination}

Free proline was extracted and measured colorimetrically following the procedure described by Bates et al. (1973). Exactly $0.5 \mathrm{~g}$ of fresh leaf material was homogenized in $10 \mathrm{ml}$ of $3 \%(\mathrm{w} / \mathrm{v})$ aqueous 5-sulfosalicylic acid and the extract was filtered through Whatman \#2 filter paper. Two $\mathrm{ml}$ of the filtrate, $2 \mathrm{ml}$ of acidic ninhydrin and $2 \mathrm{ml}$ of acetic acid were mixed in a test tube. The solution was heated using a boiling water bath $\left(100^{\circ} \mathrm{C}\right)$ for $1 \mathrm{~h}$ to allow color development. Thereafter, reaction was stopped by placing the tubes in an ice bath.

To extract the chromophore, $4 \mathrm{ml}$ of toluene were added to the tube and mixed vigorously for $15-20 \mathrm{sec}$. The extract was quantitatively transferred to a clean test tube. Absorbance of the extract was measured using spectrophotometer (Milton Roy 1001 plus) at $520 \mathrm{~nm}$. Toluene was used as blank. Stock solution of $100 \mu \mathrm{g}$ proline/ml, in $3 \%$ (w/v) 5-sulfosalicylic acid, was used and a linear standard curve was constructed over a range of 2 to 20 $\mu \mathrm{g}$ proline/ml.

\section{Results and discussion}

The average of free proline content for samples directly tested after leaves collection was $7.1 \mu \mathrm{mol} / \mathrm{g}$ (Figure1). Differences in proline contents in tomato leaves among different cultivars were found (Nahar and Gretzmacher, 2002; Jureková et al., 2011), our results are in line with these data. These slight differences in proline concentration among Jordanian landraces could be explained by the fact that the samples are from the same species and have the same genetic makeup. However, these differences indicate that Jordanian 
landraces differ in their adaptation to stress conditions through osmotic adjustment. Proline acts as an osmolite beside enzymes and other macromolecules, and therefore, protects the plant against low water potential and causes osmotic regulation in plant organs (Jureková et al., 2011).

The average values of free proline content were measured after 3,6 , and 11 weeks for samples stored at $+4^{\circ} \mathrm{C}$ and were $4.8,1.8$ and $1.1 \mu \mathrm{mol} / \mathrm{g}$, respectively (Figure 1a). The decline of free proline content during storage at $+4^{\circ} \mathrm{C}$ as shown in figure la suggests the possibility that the enzymes involved in proline degradation pathway like proline oxidase are still active.

(a) Storage at $+4{ }^{\circ} \mathrm{C}$

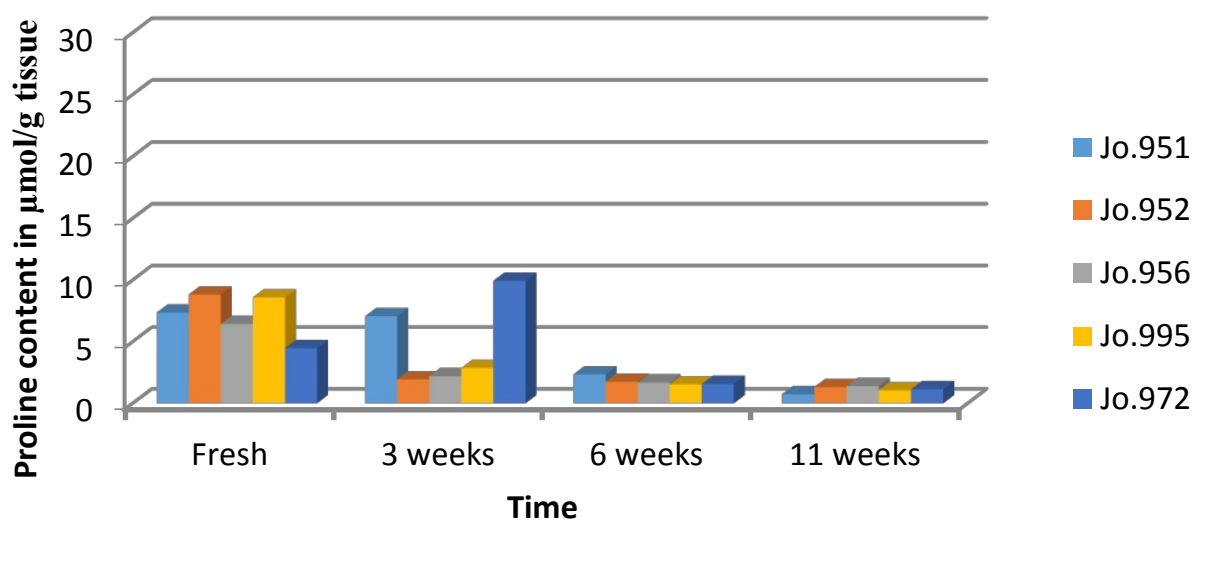

(b) Storage at $-20^{\circ} \mathrm{C}$

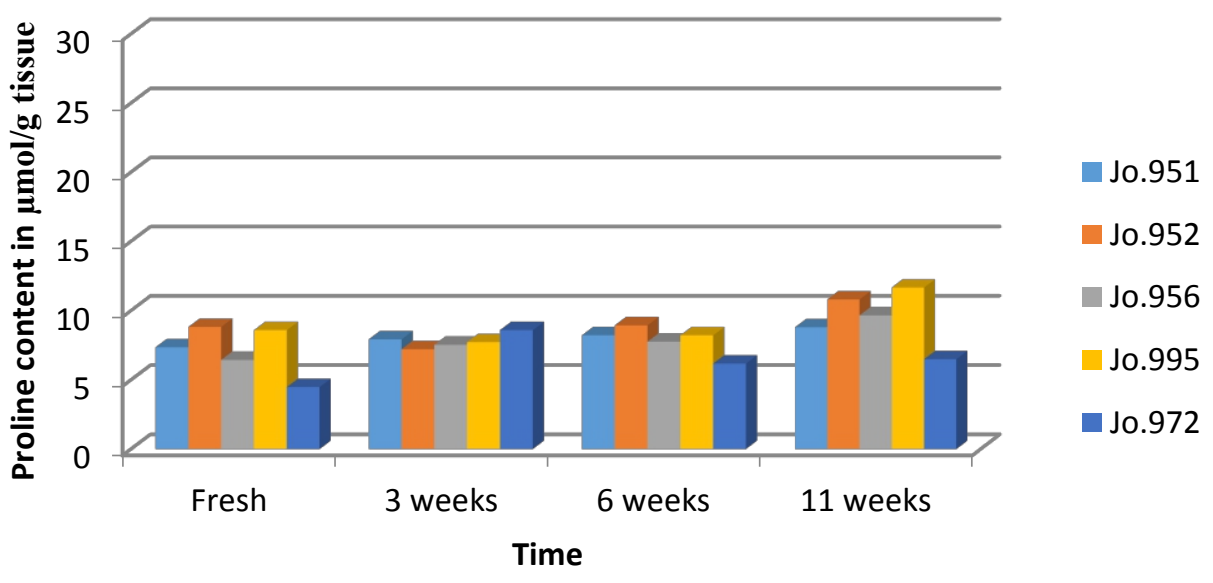


(c) Storage at $-80^{\circ} \mathrm{C}$

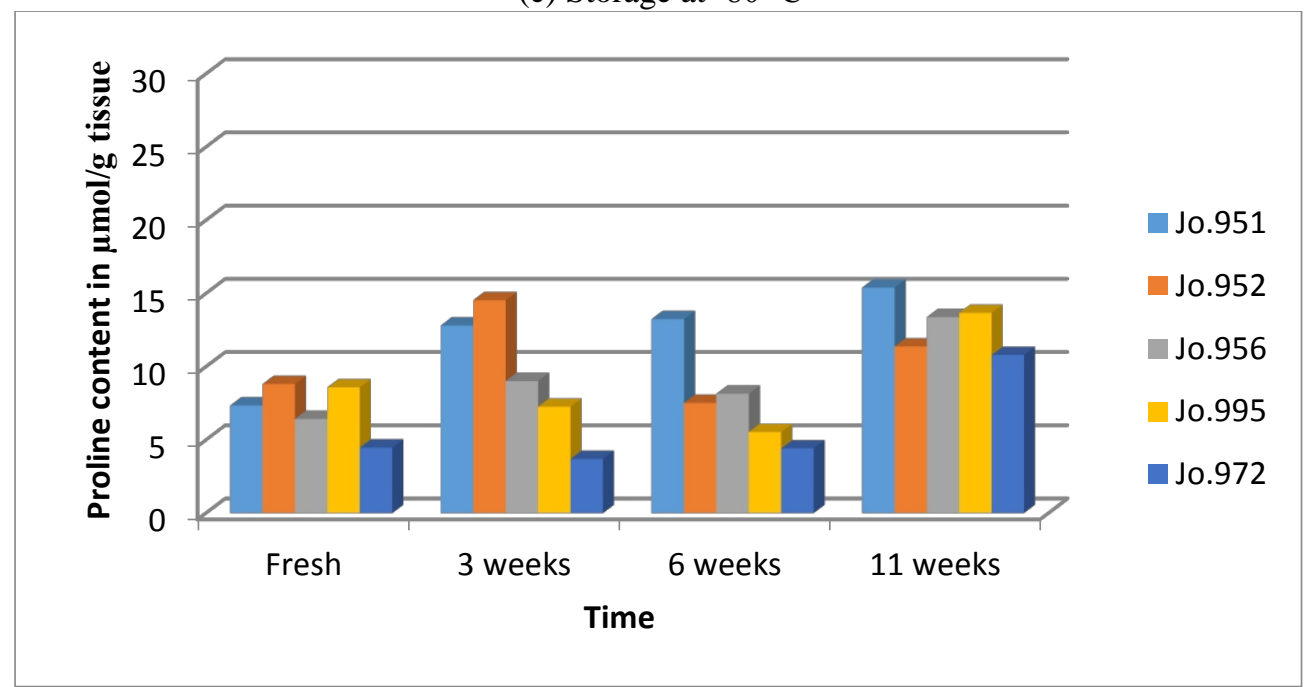

Figure 1: Free proline content of five Jordanian tomato landraces stored for $0,3,6$, and 11 weeks at $+4^{\circ} \mathrm{C},-20^{\circ} \mathrm{C}$ and $-80^{\circ} \mathrm{C}$.

The concentration of free proline content for the five tomato landraces stored at $-20^{\circ} \mathrm{C}$ measured after 3 and 6 weeks were inline with the data of proline for leaf samples measured directly after leaves collection (Figure 1b). The average values of proline concentration at $-20^{\circ} \mathrm{C}$ were $7.8,7.9$, and 9.5 $\mu \mathrm{mol} / \mathrm{g}$ after 3,6 , and 11 weeks of storage, respectively. The slight increase in proline content mainly after 11 weeks as shown in figure $1 \mathrm{~b}$ suggest the possibility that the storage condition was allowing the release of proline from subcellular location or from organelles or by the chemical breakdown of complex biomolecules which release proline over time (Teklic' et al., 2010).

For the samples stored at $-80^{\circ} \mathrm{C}$, the average values of free proline content were $9.5,7.8$, and $12.9 \mu \mathrm{mol} / \mathrm{g}$ for the measurements after 3,6 , and 11 weeks of storage, respectively. These values were higher than the control data as shown in Figure 1c. The clear increase in proline content between the control samples and the samples stored at $-80^{\circ} \mathrm{C}$ for 11 weeks could be explained by the damage effect of macromolecules and biological membranes caused by the deep freeze which will leads to increase the proline concentration. For both $-20{ }^{\circ} \mathrm{C}$ and $-80{ }^{\circ} \mathrm{C}$, our results indicated that we could store tomato leaf samples up to six weeks as longer duration of storage lead to highly increase in proline content (Figure 1b and 1c). The best procedure to avoid down or over estimation of free proline content in plant leaf samples is to prepare and measure the samples directly after leaves collection as reported by Teklic et al. (2010). But for large number of samples, keeping the samples at $-20^{\circ} \mathrm{C}$ not longer than six weeks could be a solution as mentioned in the 
results of this work. Finally, the development of in-field method for the measurements of free proline content is needed.

\section{References:}

1. Alarcon, J. J., Sanchez-Blanco, M. J., Bolarin, M. C., \& Torrecillas, A. (1994). Growth and osmotic adjustment of two tomato cultivars during and after saline stress. Plant and Soil, 166: 75-82.

2. Aloni, B., \& Rosenshtein, G. (1984). Proline accumulation: A parameter for evaluation of

3. sensitivity of tomato varieties to drought stress. Physiologia Plantaurm, 61(1): 231-235.

4. Balibrea, ME., Rus-Alvarez, AM., Bolarin, MC., \& Perez-Alfocea, F. (1997). Fast changes in

5. soluble carbohydrates and proline contents in tomato seedlings in response to ionic and non-

6. ionic iso-osmotic stresses. J Plant Physiol 151: 222-226.

7. Barrow, J. R., Lucero, M. E., Reyes-Vera, I., \& Havstad, K. M. (2008). Do symbiotic microbes have a role in plant evolution, performance and response to stress?. Commun Integr. Biol. 1(1): 6973.

8. Bates, L. S., Waldren, R. P., \& Teare, I. D. (1973). Rapid determination of free proline for water stress studies. Plant and soil, 39(1): 205-207.

9. Bilton, R., Gerber, M., Grolier, P. \& Leoni, C. (2001). The White Book on Antioxidants in

10. Tomatoes and Tomato Products and Their Health Benefits. Chapter 2, 2-47 CMITI,

11. Avignon, 2001, ISSN 1145-9565.

12. Bourgeais-Chaillou, P., \& Guerrier, G. (1992). Salt-responses in Lycopersicon esculentum

13. calli and whole plants. Journal of plant physiology, 140(4): 494-501.

14. Cuartero, J., Bolarín, M. C., Asíns, M. J., \& Moreno, V. (2006). Increasing salt tolerance in the tomato. Journal of Experimental Botany, 57(5): 1045-1058.

15. Delauney, A. J., \& Verma, D. P. (1993). Proline biosynthesis and osmoregulation in plant. The Plant Journal, 4(2): 215-223. 
16. Deshmukh, R. S., Patil, N. A., \& Nikam, T. D. (2012). Influence of kunapajala treatment from vrikshyaurveda on the fruits of tomato under organic farming condition and its comparison with N.P.K. farming. Bioscience Discovery, 3(2): 200-206.

17. Eisenstein, M. (2013). Discovery in a dry spell. Nature, 501: S7-S9.

18. García-Closas, R., Berenguer, A., José Tormo, M., José Sánchez, M., Quirós, JR., Navarro, C., Arnaud, R., Dorronsoro, M., Dolores Chirlaque, M., Barricarte, A., Ardanaz, E., Amiano, P., Martinez, C., Agudo, A. \& González, CA. (2004). Dietary sources of vitamin C, vitamin E and specific carotenoids in Spain. Br J Nutr, 91(6): 10051011.

19. Guerrier, G. (1995). Effect of salt-stress on proline metabolism in calli of Lycopersicon

20. esculentum, Lycopersicon pennellii, and their interspecific hybrid. Journal of Botany, 73(12):

21. 1939-1946.

22. Guerrier, G. (1998). Proline accumulation in salt-treated tomato : Different praline precursors

23. in Lycopersicon esculentum and Lycopersicon pennelli. Journal of Plant Nutrition, 21(3):

24. 505-513.

25. Hu, C. A., Delauney, A. J. \& Verma, D. P. (1992). A bifunctional enzyme (delta 1-pyrroline-5-carboxylate synthetase) catalyzes the first two steps in proline biosynthesis in plants. Proc.Natl. Academic Science, 89(19): 9354-9358.

26. Jureková, Z., Németh-Molnár, K., \& Paganová, V. (2011). Physiological responses of six tomato (Lycopersicon esculentum Mill.) cultivars to water stress. J. Hortic. For 3(10): 294-300.

27. Liu, J., \& Zhu, J. K. (1997). Proline accumulation and salt-stressinduced gene expression in a

28. salt-hypersensitive mutant of Arabidopsis. Plant Physiology, 114(2): 591-596.

29. Lutts, S., Majerus, V., \& Kinet, M. (1999). NaCL effects on proline metabolism in rice (Oryza sativa L.) seedlings. Physiologia Plantarum, 105(3): 450-458. 
30. Nahar, K., \& Gretzmacher, R. (2002). Effect of water stress on nutrient uptake, yield and

31. quality of tomato (Lycopersicon esculentum Mill.) under subtropical conditions. Die

32. Bodenkultur, 53(1): 45-51.

33. Riaze, A., Matsuda, K. \& Arslan, A. (1985). Water-stress induced changes in concentrations of proline and other solutes in growing regions of young barley leaves. Journal of Experimental Botany, 36(11):1716-1725.

34. Smith, D. (2006). The State of the Middle East: An atlas of conflict and resolution,

35. Routledge, London.

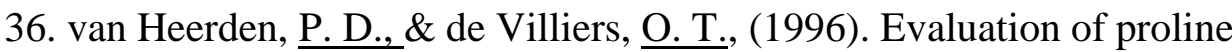
accumulation as an

37. indicator of drought tolerance in spring wheat cultivars. South African Journal of Plant and

38. Soil, 13(1): 17-21.

39. Yang, J., Kloepper, JW., \& Ryu, CM. (2009). Rhizosphere bacteria help plants tolerate abiotic

40. stress. Trends Plant Sci., 14(1): 1-4.

41. Yoshiba, Y., Kiyosue, T., Nakashma, K., Yamaguchi-Shinozaki, K., \& Shinozaki, K. (1997).

42. Regulation of levels of proline as an osmolyte in plants under water stress. Plant Cell

43. Physiology, 38(10): 095-1102. 